w tomie pokonferencyjnym. Zatem z ich treścią będą mogły się zapoznać wszystkie osoby zainteresowane sprawami edukacji wielokulturowej. Wydaję się, iż formuła konferencji daleka jest od wyczerpania, można zatem spodziewać się kolejnej, VII już, edycji międzynarodowego spotkania naukowców w częstochowskiej Akademii im. Jana Długosza.

Izabela Wrona

\title{
„Wychowanie w rodzinie. Konteksty historyczne i współczesne” konferencja naukowa Uniwersytetu Wroclawskiego i Kolegium Karkonoskiego (Jelenia Góra - Szklarska Poręba, 27-28 maja 2010)
}

W dniach 27-28 maja 2010 r. w Jeleniej Górze odbyła się Międzynarodowa Konferencja Naukowa pt. „Wychowanie w rodzinie. Konteksty historyczne i współczesne”. Konferencja zorganizowana została przez Zakład Historii Edukacji Instytutu Pedagogiki Uniwersytetu Wrocławskiego oraz Wydział Humanistyczny Kolegium Karkonoskiego w Jeleniej Górze.

Konferencję zainaugurować jej inicjatorka i promotor prof. dr hab. Stefania Walasek (Uniwersytet Wrocławski). Następnie dr Leszek Albański (Kolegium Karkonoskie) powitał zebranych gości oraz uczestników.

Konferencję rozpoczęły obrady plenarne, których moderatorem była prof. dr hab. Dorota Żołądź-Strzelczyk (UAM Poznań). Interesujące wystąpienie wygłosił prof. dr hab. Wiesław Jamrożek (UAM Poznań i ŁWSH w Żarach) na temat „Rodziny w poglądach działaczy i teoretyków galicyjskiej socjalnej demokracji”. Prof. dr hab. Krystyna Ferenz (Uniwersytet Wrocławski) zainteresowała zebranych referatem „Komunikacja niewerbalna w rodzinie jako wyraz więzi". Goście z Republiki Czeskiej, profesorowie Uniwersytetu Masaryka w Brnie - Maria Mareckova i Jaroslav Vaculik, rozważali fenomen rodziny w Europie Środkowej. Prof. Vaculik przedstawił sytuację rodzin Czechów na Wołyniu. Obrady plenarne zakończyła dyskusja.

Po przerwie uczestniczy udali się na debaty w następujących sekcjach tematycznych:

I. Rodzina w tradycji i kulturze polskiej

Podsekcja 1 - Rodzina i wychowanie dzieci w XIX wieku (moderator: prof. dr hab. Barbara Jędrychowska). Wystąpienia odnosiły się do miejsca, roli rodziny, kobiety, wychowania na łamach czasopiśmiennictwa i podręczników oraz rodziny jako środowiska edukacyjnego.

Podsekcja 2 - Rodzina w latach II Rzeczypospolitej (moderator: prof. dr hab. Krzysztof Jakubiak). Obszarem zainteresowań uczestników było kształtowanie pedagogiki rodziny w II RP; tematyka rodziny w elementarzach, publikacjach J. Becka, programach 
historii; ewolucja, różnorodne aspekty i znaczenie rodziny w wychowaniu w środowisku wiejskim i wojskowym.

Podsekcja 3 - Rola tradycji w wychowaniu rodzinnym na przestrzeni wieków (moderator: prof.dr hab. Grzegorz Michalski). Referaty prezentowały osobliwości rodzin żydowskich, łemkowskich, tatarskich; rodziny międzykulturowe; twórczość J. Rybowicza; rolę tradycji i kultury rodziny polskiej w określonym czasie, aspektu historycznego wychowania do życia w rodzinie. Interesujace wystapienie prof. dr. hab. A. Ładyżyńskiego dotyczyło ewolucji narzeczeństwa.

II. Współczesna rodzina w sytuacji zmiany (moderator: prof.dr hab. Krystyna Ferenz). Wystąpienia odnosiły się do skutków przemian w obszarze rodziny; udziału polityki, mediów w realizacji wychowawczej funkcji rodziny.

III. Dziecko niepełnosprawne w rodzinie (moderator: prof.dr hab. Aleksandra Maciarz). Uczestnicy podejmowali różnorodne aspekty funkcjonowania rodziny z niepełnosprawnym dzieckiem w przeszłości i teraźniejszości; udział poradnictwa rodzinnego, psychologiczno-pedagogicznego w procesie wychowania i kształcenia dziecka niepełnosprawnego.

IV. Rodzina w sytuacjach zagrożenia (moderator: prof.dr hab. Bożena Matyjas). Wystąpienia odnosiły się do aktualnych zjawisk społecznych i ich wpływu na funkcjonowanie rodzin - bezrobocie, rozwód, samotność młodzieży, macierzyństwo w więzieniach.

V. Praktyczne aspekty pomocy w rodzinie (moderator: prof.dr hab. Eleonora SapiaDrewniak). Tematyka wystąpień odnosiła się do instytucjonalnych form pomocy rodzinie, miejsca polityki rodzinnej w strukturach samorządowych.

W godzinach wieczornych uczestnicy udali się do Szklarskiej Poręby, gdzie odbyła się uroczysta kolacja.

W drugim dniu konferencji dokonano podsumowania obrad. Uczestnicy złożyli podziękowania Organizatorom za podjęty wysiłek organizacyjny oraz stworzenie naukowej platformy wymiany wiedzy i doświadczeń. Prof. dr hab. Stefania Walasek podziękowała zebranym za uczestnictwo w obradach. Chętni uczestnicy wybrali się na integracyjną wycieczkę w góry.

Organizatorzy konferencji poinformowali o druku referatów. 